\title{
Examining the Quest for the Historical Jesus and its Relevance Today
}

\author{
Peter Addai-Mensah' ${ }^{1}$
}

${ }^{1}$ Department of Religious Studies, Kwame Nkrumah University of Science and Technology, Kumasi Ghana.

\begin{abstract}
The Akans of Ghana have a proverb that says, tete wo bi ka, tete wo bi kyere nti hwe na sua - which literally means - the past has something to say, it has something to teach, therefore, learn from it. It emphasizes the importance and significance of History. History enables humanity to look at the past with the view to understanding the present in order to make projections into the future. Jesus Christ is one person who has influenced humanity very significantly. However, Jesus Christ lived in a different era. In order to understand him and see his relevance, there is the need to enter the world in which he lived and see whether his life and teachings make sense today. This necessitates the fusion of two horizons. It calls for deconstruction and construction again of the life and ministry of Jesus to make his teaching more meaningful and significant for people of today. This article discusses the search for the Jesus of History; whether this quest is possible and the relevance for this quest for contemporary society. The purpose of writing this article is to retrieve the significance of Jesus Christ in Salvation History and make Him relevant in contemporary society.
\end{abstract}

Keywords: Deconstruction, Demythologize, Fusion of Horizons, Historical Jesus, Reconstruction and Quest

(C) 2020 The Author(s). Published and Maintained by Noyam Publishers.

This is an open access article under the CCBY license (http://creativecommons.org/licenses/by/4.0/)

\section{INTRODUCTION}

One discipline that has become so important to human beings is history. People are very particular in tracing their lineages or origins. In recent years, some African - Americans have traced their history to some places and families in Africa. They are so interested to be in linked with their roots. The historical consciousness has caught up with the church also which is a community of people. The church traces her origin to Jesus Christ. Available evidence shows that it was not the intention of Jesus to establish a separatist group like the Essene or to establish a church. ${ }^{1}$ Jesus' aim on earth was to establish the Kingdom/Reign of God. He preached a gospel of repentance and called people to change their way of life so as to enter into the kingdom. In addition to the proclamation of the gospels, Jesus came to proclaim release to the captives and recovering of sight to the blind, to set at liberty those who were oppressed-cf. Lk. 4:18-19). ${ }^{2}$ Since he was a threat to the political as well as the religious leaders, he was put to death. As a result of his ministry, Jesus gained a lot of followers. These followers did not perish after his death. They continued to exist and they have flourished into the present - day church. The church, therefore, came into being as a result of the ministry of Jesus even though it was not his avowed aim to establish a church. The church accordingly sees Jesus as its foundation. ${ }^{3}$ It exists solely to carry out the mission of Jesus who was also sent by God- (cf. Jn. 17: 1-25).

As a community of human beings, the church did not come out of the blue. It was born into a particular sociopolico-cultural setting. As such, it was subjected to historical development. As it grows into other places, it takes the cultural setting of the place into consideration. It is affected by the great changes that occur in human history. This

\footnotetext{
Roger Haight, ”Historical Ecclesiology” Science et Esprit XXXIX (1987), 37; John P. Meier “Reflection on Jesus-of-History Research Today “Jesus Jewishness (New York: 1990), 90.

All the scriptural quotations are from the New Revised Standard Version.

Francis Schussler Fiorenza, Foundation Theology: Jesus and the Church (New York: 1985), 162.
} 
development has gone on for years. The church, therefore, has acquired many faces as it has gone through and continues to go through the various periods in history.Since the nineteenth century, there have been attempts to research into Jesus who has influenced the human history very much. These studies have been done and continue to be done by Christians, Jews and agnostics alike.

This article seeks to examine the life of Jesus Christ as he lived in the first century. His life has influenced many people over the centuries. This article seeks to sift through the life of Jesus Christ and make him relevant to society today.

\section{METHODOLOGY}

Various approaches are used in writing articles. They include qualitative, quantitative and mixed-method approaches. The author chooses the literary approach in writing this article.

\section{The Meaning of the Historical Quest:}

Many who undertake the historical search are of the view that the gospels and the church do not give an accurate and authentic picture of Jesus. They think that the picture of Jesus has been coated with creedal statements by the early Christian writers. They want to see Jesus from the historian's point of view and not in the believers view. They, consequently, adopt a scientific approach to reclaim who Jesus really was. Most of the time a search for the historical Jesus means peeling away various layers of interpretation given to Jesus by his followers. This involves demythologizing Jesus which tends to reject the miracles, the empty tomb and even the divinity of Jesus as "inappropriate ideas and therefore non-factual." As Harrington noted which is an opinion shared by the author, "the idea behind this quest is to go beneath the surface of the gospels to peel away the accretions made in the process of transmission, and so to arrive at Jesus of Nazareth - as he really was." 4

\section{The Origin of the Quest}

All along history, there have not been attempts to reconstruct Jesus in any way. The gospels' portrayal of Jesus has never been questioned. The quest for the historical Jesus began as a result of the European enlightenment. It actually started in the period of 1774 - 1778 when The Fragments written by Reimarus was published after his death. ${ }^{5}$ From that time, scholars began to write a biography of Jesus. One of such scholars who saw the need to pursue an unbiased historical research was Strauss. His book, Life of Jesus was acclaimed a master - piece during his period. There are other scholars like Kahler, who could not see how the Christian faith could be in harmony with the history of Jesus. He saw the gospels as post - Easter confessionals.Forhim theywill repeleachother. ThisinsightfromKahlerinfluenced peoplelikeBultmann,EarthandTillich. ${ }^{6}$ According to Bultmann, there is nothing that can be known about the life and personality of Jesus. This is because the early Christian writers were not interested in that. Furthermore, he went on to say that there are no other sources about Jesus. ${ }^{7}$

The author agrees with Bultmann that there are no other sources from which man can now about Jesus. It must be said that the quest for the historical Jesus waned down greatly at the beginning of the twentieth century. However, Bultmann's ideas were not wholly accepted. One of the accusations against him is that he did not show any interest in archaeology and the land of Israel. He did not attempt to see the literary deposits of early Judaism that are contemporaneous with Jesus. His assertion that the early Christian writers did not show any interest in the life and personality of Jesus is not accurate. A closer look at the writers shows that they were at pains to portray who Jesus was especially to non - believers. A scholar who did not share the views expressed by Bultmann was his own student, Kasemann. According to Kasemann, researchers can only know what happened in time passed only through the tradition available.This can be made clear when it is interpreted. ${ }^{8}$ This means that the gospels are interpretated traditions. They do preserve the continuing efficaciousness of tradition for faith. At the same time, they provide a way back to the Jesus of history. During the 1950's, many scholars who had shunned the quest for the historical Jesus resumed the task. This task gathered momentum especially in the 1980's.

\section{The possibility of the quest}

The author posits that the quest for the historical Jesus humanly speaking is impossible. This is because Jesus did not leave an autobiography. He was an iterant preacher who went about proclaiming the coming of the kingdom of God, a kingdom of peace, justice and joy - (cf. Rom. 14:17). He called people to repentance and saw himself as sent by God to bring good news to the poor, release to captives, recovering of sight to the blind and to proclaim the accepted year of the Lord- (cf. Lk.4 : 18 - 19). The urgency of his message and the immense dawning of the kingdom did not even allow him to organize a special group and to set up structures, let alone write a book about his life. For him, the best way to

\footnotetext{
Dan Harrington, "The Jewishness of Jesus facing some Problems” Jesus Jewishness, 132.

James H. Charlesworth "The Foreground of Christian Origins and the Commencement of Jesus Research Jesus Jewishness, 78.

Charlesworth, "The Foreground of Christian Origins and the Commencement of Jesus Research", 79.

Charlesworth, "The Foreground of Christian Origins and the Commencement of Jesus Research" 79.

Charlesworth, "The Foreground of Christian Origins and the Commencement of Jesus Research", 81.
} 
know about him was not to read or hear about him. Rather, it was to follow him and live his way of life.

The closest that can be known about Jesus is from what the gospels provide. The writers were people who had experienced Jesus. Some of them had spent a lot of time with him and knew much about him. Those who wrote the gospel did not do so as professional historians would do. In the first place they did so because of their faith in Jesus. Secondly, they proclaimed him as the Son of God, Lord and Savior. They proclaimed that this Jesus was arrested and crucified. After his death, he rose into glory. A critical look at the gospels shows that there are a lot of discrepancies. For example, Mark and John presented the adult Jesus beginning with his ministry that lasted for a few years. Matthew and Luke have some infancy narratives, the accounts of which are even doubtful, prior to the public ministry of Jesus. In addition to that the true historical sequence of the events of Jesus' public ministry is not known. While the Synoptic Gospels placed the Jesus ministry primarily in Galilee, the fourth gospel concentrated Jesus ministry rather in Judea and Jerusalem.

There are a lot of things not know about Jesus. There is not much known about Jesus' "hidden life" from the time he was twelve after the presentation in the temple till he began his public ministry at about the age of thirty. Furthermore, there are many things that Jesus said or did that were never recorded- (cf. Jan, 21:25). At best known are three or four years of Jesus public ministry. How can one construct a biography (in the modern sense) of Jesus when he/she knows only some selected events of his life?

Apart from the gospels, scholars look to other Jewish sources for information about Jesus in the first century Palestine. But there is not much to be gained from there. First century Judaism did not see Jesus as so important a person to write about him. It saw him as one of those who got themselves into trouble with the authorities and so got a shameful death. Even accounts from people like Josephus and Tacitus are simply reports of something about what early Christians were doing or saying. They do not supply any independent witness of Jesus himself. ${ }^{9}$ So aside of the gospels, there are no ways to get to Jesus, the Jewish sources available now are either late or suspect As Harrington puts it, any attempt to go behind the gospels to find the real Jesus will be an exercise in futility. ${ }^{10}$ This is a view shared by the author. The author thinks that even if Jesus had written an autobiography or the gospels had constructed a biography in the modem sense of the word, humanity could still not have known the real Jesus. This is because there is a big difference between reading or knowing about a person and what that person really is.That is to say, despite the advancement in the media landscape with the invention of television, videos, cameras and printed materials, there is not much know about the total reality of somebody like Martin Luther King, Jr. At least a lot is known about him, for example, where he was born, his parents, where he lived, and was educated, died and was buried. However, that will not complete a full knowledge about him. This is because researchers will not be able to know his feelings, his thoughts and many things he did or said. The same can be said about Jesus who lived in the first century when even modem technologies were non - existent. If with modem technologies researchers cannot portray the real picture of a person in today's world, how can the real Jesus who lived so many years ago be known into details? The historical research can help one to know something about Jesus. It can show that Jesus lived during the first century in Palestine and had Mary and Joseph as parents. It can tell that his fellow Jews saw him as a prophet from God who went about preaching repentance. It can also show that he gained a lot of followers but he was killed because he was a threat to the authorities. What the historical research cannot offer is the real Jesus. This is because the Jesus of history cannot be the real Jesus. In addition, the real Jesus is not the same as the Jesus of history. ${ }^{11}$ The questers, in their attempts to get behind the gospel and offer an authentic and "unadulterated" picture of Jesus, demythologize Jesus and do not include his miracles, the empty tomb and his divinity. This is a kind of reductionism. Research cannot paint a true portrait of a person if half of the person's life or activities is completely and deliberatively cut off. So, from the onset, those who want to study about Jesus but do not include certain aspects in his life miss the point. Some Jewish scholars have nowadays taken interest in studying Jesus.

Vermes, in his book Jesus the Jew situated Jesus in the first century Judaism. He tried to point out in the book that the miracles of Jesus were not peculiar to him alone. There were others like Honi, the circle drawer who lived in the first century before Christ who perform miracles and had influence on natural phenomenon. ${ }^{12}$ One character that Vermes paralleled so well with Jesus was Hannina ben Dosa. Like Jesus he could cure all kinds of diseases and could even heal from a distance. He was credited with the ability to influence natural phenomenon and could forgive sin. ${ }^{13}$ According to Vermes the language and the behavior of Jesus were not peculiar to him. There were other people before him who acted in a similar way. ${ }^{14}$ The inference that Vermes drew was that "the person of Jesus is to be seen as part of the first century

\footnotetext{
$\overline{9}$ Meier, A Marginal Jew (New York:1991), 91.

10 Harrington, "The Jewishness of Jesus facing some Problems",133.

Meier, A Marginal Jew, 21.

2 Geza Vermes, Jesus the Jew (Philadelphia: 1973) ,69.

3 Vermes, Jesus the Jew 72.

Vermes, Jesus the Jew, 117.
} 
charismatic Judaism and as the paramount example of the early Hasidim or Devout."15 In sum, the author agrees with Meier that the real Jesus through historical research cannot be known because the real Jesus is not available and never will be. ${ }^{16}$ Secondly, the historical quest adopts a kind of reductionist approach and cannot therefore offer a complete and holistic picture of Jesus' life and personality.

\section{African Scholars on the Historical Quest}

Many African scholars have written about Jesus Christ. This is to make him meaningful in African context.For this reason, a lot of research has been made in Christology. Consequently, research has produced a lot of Christologies. Jesus Christ is therefore seen as Great Ancestor,Ancestor par-excellence, Guest and many others. ${ }^{17}$ With regard to the historical quest, it is an area that is gaining grounds in recent times.Some African scholars who have taken interest in the historical quest include: Emmanuel Asante; ${ }^{18}$ John Ariechi Ottuh; ${ }^{19}$ Justin S. Ukpong ${ }^{20}$ and Emmanuel Orobator. ${ }^{21}$ The approach that these African scholars use is the inculturation paradigm. The aim is to reconstruct Jesus to make him more meaningful in the African context. This is because "it is not the Christian God who causes problem for Afro cultures; it is the Christian Christ." ${ }^{22}$ It must be pointed out that many African scholars see Jesus of Nazareth (Historical Jesus) as the same as Jesus of the Christian faith.

\section{The Relevance of the Quest}

There is disagreement among scholars as regards the relevance of quest for the historical Jesus. As mentioned earlier on scholars like Mahler and Bultmann do not see it as necessary. At least it cannot help them in their faith. The same view is partially showed by John Meier when he said that his faith in Jesus will not wane down because of the search for the Jesus of history. The Jesus of history he sketches "is at best a fragmentary, hypothetical,changeable reconstruction; it is not - and could hardly be - the object of the church's faith and preaching." ${ }^{23}$ This is not to say that Meier did not see the quest as necessary. For him, the quest can get to the historical Jesus and not the real Jesus who is the object of his faith. ${ }^{24}$

The author takes the position of Meier and states that despite what has been said above that quest for the historical Jesus is impossible but it is still necessary.It has enabled Christians to be firmly grounded in their roots. It has shown that Jesus whom Christianity traces its foundation to was not an imaginary being like Santa Claus. At least it has shown that Jesus actually lived and was born into a particular human culture which was Jewish in the first century. It has affirmed that certain things that Jesus did can be compared to others in first century Judaism.

Furthermore, if the crucifixion and the resurrection which are the bases of the Christian faith are historically disproved, the Christian faith will suffer because it will be based on false assumptions.

The historical quest has opened widely the door to ecumenism. There are now many Jewish scholars trying to study Jesus. Even though some dismiss him as an apostate, there are manyothers who seehimas a brother Jew and placehim within the boundaries of Judaism, The latter sees Jesus' teachingas havingbeen distorted by theearly church in her attempttopreach to the gentiles. One Jewish author who claimed to conduct an independent and unbiased study about Jesus was Vermes. ${ }^{25}$ He tried to place Jesus in Judaism of his time. Vermes as noted earlier on compared the ministry of Jesus with other Jewish prophets. He studied the various titles given to Jesus and pointed out that they were not peculiar to Jesus.

Even though Jews and Christians differ in their theological assessment of Jesus (Jews see Jesus as a rabbi and somebody who suffered for what he stood for, Christians consider him as an authoritative interpreter of the Law, and savior of the world), they have a common ground to talk about in the Jewish - Christian dialogue urged on by the Vatican II- (cf. Nostrae Aetate no. 4). The quest has brought the two groups together more than ever.

The quest for the historical Jesus has not only helped in the Jews - Christian dialogue but also dialogues with churches like Catholic - Orthodox, Lutheran-Catholic and Catholic- Anglican dialogues. Through the study the church has realized that there are certain things that are essential to the gospel message. Others are, however, accidental. Through historical consciousness, the church knows that it was not the intention of Jesus to found a church. However, a community of disciples that followed him remained after his death. This community has grown into the present day church and carries on the mission of Jesus. It enables the church to see that Jesus did not give specific structures to the

\footnotetext{
15 Vermes, Jesus the Jew, 79.

16 Meier, A Marginal Jew, 22.

17 Yvon C. Elenga, "African Christologies: Naming Jesus", Theology Digest,49 no. 3 (2002): 229-232.

Asante,E, "Jesus the Christ: A Survey of the Christological Quest” Kumasi:Walas Press.(2009) ISBN9988-7815-4-7.

19 John Ariechi Ottuh, Bible Research in African: Historical Jesus Quest in Inculturation Perspective., Academic Journal of Interdisciplinary Studies 4, no 2 (2015): 183-198

20 Justin S. Ukpong, Historical Jesus Research in Anglophone Africa. Department of Religious and Cultural Studies, University of Ugo, 1-14.

21 Emmanuel, Orobator, “The Quest for an African Christ: An Essay on Contemporary African Christology”, Hekima Review, No 11. September 1994, 75-99.

Robert E. Hood, Must God remain Greek?: Afro Cultures and God-Talk. Minneapolis, Fortress Press, 1990,145

Meier, A Marginal Jew,87.

Meier, A Marginal Jew , 24.

Vermes, Jesus the Jew,109.
} 
church. However, as the community of disciples began to proclaim the good news to Jews and non - Jews alike, new situations and challenges emerged. Consequently, structures and ministries began to be instituted in the church. Leaders were for example, appointed to the emerging communities. Some members were commissioned to serve the needs of widows and the poor - (cf. Acts 6:1ff), others were chosen to preside over the community's assembly once Christianity broke away from Judaism. All these were ministries given to community members for service to the community to enhance the mission of the community of disciples depending on individual's commitment and willingness to serve the community. So through the quest, the church knows that various structures and ministries in the church arose as a result of needs and concerns of the growing church. This will enable the Catholic Church especially to enter deeply into dialogue with other sister churches about certain things in the church unity instead of holding tenaciously to them as coming from Jesus. Secondly, the historical quest will enable the church to take decisions that will help the church in her mission on earth as the need arises just as it was done in the apostolic era.

The relevance of the historical quest can be seen not only in Christian - Jewish dialogue and dialogues among the various churches. As a result of the quest for the historical Jesus, even agnostics are taking great interest in studying Jesus. Even though, they do not accept the divinity of Jesus, they are moved by the values that he stood for and his concern for the emancipation of the - human person. Milan Machovec in his book, paid a growing tribute to the historical quest. He acknowledged the fact that "there has been a real transformation in the relations between Christianity and Marxism and that if somebody now hundred years after Marx simply repeated or re- emphasized what he once said, then this 'fidelity' to the conceptual system would be an abandonment of the original real and alert sense for what is new in history."26

Machovec was of the view that one would have to be a liar or acynic to deny that the twentieth century has seen a lot of things that Karl Marx hadnot the slightest idea of. For him, modern theologians have come up with new ideas of discussing God that has made great impressions upon Marxists. Marxists no longer know whether they could continue to consider themselves as atheists or not. ${ }^{27}$

\section{RECOMMENDATIONS}

The author will like to make the following recommendations:

1. The quest for the Historical Jesus must continue.

2. The difference of the Historical Jesus and the Jesus of Faith must be distinguished.

3. The quest for the Historical Jesus must be opened to all scholars.

4. Followers of Jesus must be open-minded in sitting at table to discuss Jesus with others of different faith.

\section{CONCLUSION}

In this article, the author has looked at the quest for the historical Jesus and to see whether it is necessary or not. The author ends by saying that if through the quest the main aim is to know the real Jesus, then that is not possible. This is because research is limited by the sources available. Also, an autobiography of Jesus has never been available. The sources that are available - the gospels - are not biographies in the modern sense of the word. There are no other authentic sources apart from the gospels. Finally, even if these sources were present, they would still not give a true picture of Jesus. The reason being that reading or knowing about a person is different from whom the person really is. However, if the aim is to have some knowledge about Jesus and not his total personality, then that is possible as history teaches some elements about the past. In summary, the historical quest for the real Jesus is impossible. Nevertheless, it is necessary and relevant for contemporary society.

\section{ABOUT AUTHOR}

Peter Addai-Mensah is a Catholic priest and a Senior Lecturer at the Department of Religion Studies, Kwame Nkrumah University of Science and Technology (KNUST). His research is focused on Theology and Spirituality.

\section{BIBLIOGRAPHY}

Asante, E., "Jesus the Christ: A Survey of the Christological Quest" Kumasi:Walas Press.(2009) ISBN 9988-7815-4-7. Charlesworth, H. James. "The Foreground of Christian Origins and the Commencement of Jesus Research", Jesus Jewishness. New York: The Crossroad Publishing Company, 1991.

Elenga, Yvon, C. “African Christologies: Naming Jesus", Theology Digest. 49, (3), 229-232.

Fiorenza, S. Francis. Foundational Theology: Jesus and the Church. New York: The Crossroad Publishing Company, 1985. Flannery, Austin. Vatican Council II. New York: Costello Publishing Company, 1976.

\footnotetext{
26 Milan Machovec, A Marxist looks at Jesus (Philadelphia: 1976), 25

27 Machovec, A Marxist looks at Jesus 21
} 
Haight, Roger. "Historical Ecclesiology" Science et Espirit XXXIX, 1987.

Harrington, Dan. "The Jewishness of Jesus facing Some Problems" Jesus Jewishness. New York: The Crossroad Publishing Company” 1991.

Hood, R. E. Must God remain Greek? : Afro Cultures and God-Talk. Minneapolis: Fortress Press,1990.

Machovec, Milan. A Marxist looks at Jesus. Philadelphia. Fortress Press, 1976.

Meier, P. John. "Reflections on Jesus of History: Research Today", Jesus Jewishness. New York: The Crossroad Publishing Company, 1991.

A Marginal Jew. New York. Doubleday, 1991.

Orobator, Emmanuel. "The Quest for an African Christ: An Essay on Contemporary African Christology", Hekima Review, no. 11, September, 1994, 75-99.

Ottuh, Arierchi John. "Bible Research in African: Historical Jesus Quest in Inculturation Perspective." Academic Journal of Interdisciplinary Studies 4, no 2 (2015): 183-198. http://dx.doi.org/10.5901/ajis.2015.v4n2p183

Ukpong, J. S. Historical Jesus Research in Anglophone Africa. A paper presented at The Department of Religious and Cultures Studies, University of Ugo, 2008, 1-14.

Vermes, Geza. Jesus the Jew. Philadelphia. Fortress Press, 1973. 